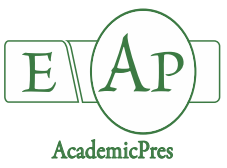

Ben Mansour-Gueddes S et al. (2020)

Notulae Botanicae Horti Agrobotanici Cluj-Napoca 48(1):436-455

DOI: $10.15835 /$ nbha48111615

Research Article

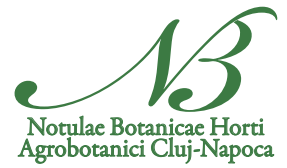

\title{
Climate change effects on phytochemical compounds and antioxidant activity of Olea europaea $\mathrm{L}$.
}

\section{Samia BEN MANSOUR-GUEDDES*, Dhouha SAIDANA-NAIJA, Ameni BCHIR, Mohamed BRAHAM}

\author{
Olive Tree Institute, Ibn Khaldoun BP 14, 4061, Sousse, \\ Tunisia;bm_samiatn@yahoo.fr (*correspondingauthor);dhoubasaidana@yahoo.com;Ameni.bchir@gmail.com; \\ braham2015@yahoo.fr
}

\begin{abstract}
To tolerate water shortage and high temperature, olive cv. 'Meski', the main variety of table olives in Tunisia, developed several biochemical changes. The hereby study focused on the adaptation of the olive tree to the climatic conditions, considering the evaluation of phenolic compounds, chlorophylls, carotenoids, saponin and steroid synthesis, as well as the evaluation of the antioxidant activity. The analyses were made upon fresh leaves collected from three coastal areas of Tunisia (North (sub-humid), Center (higher semi-arid) and South (lower arid)) and using different leaves' extracts. The results emphasized that Southern 'Meski' trees had leaves with more polyphenols, flavonoids, o-diphenols and tannins compared with the Northern ones. From the North to the South, 'Meski' leaves showed an increase of carotenoids and a decrease of chlorophyll $a$ and $b$ contents. The highest level of antioxidant compounds of Southern leaves could be contributed to reduce the oxidative stress of the olive tree. The spectrophotometric analysis of the antioxidant capacity of leaves collected from Central and Southern areas, based on DPPH and ABTS radical-scavenging activity, showed a higher value of antioxidant activity than the Northern ones, at different extract concentrations. Therefore, the increase of the analyzed bioactive compounds can be considered as a response of the tree to surround aggressions and to oppose the oxidative stress that results from the severity of climatic conditions, characteristic of the Southern area.
\end{abstract}

Keywords: bioactive compounds; biological properties; climatic conditions; leaves; olive tree

\section{Introduction}

Olive tree (Olea europaea L.) is one of the most important crops in the Mediterranean regions. Their cultivation in Tunisia is of great agronomic and socio-economic importance. The Tunisian olive forest covers 1.8 million ha and has around 80 million olive trees distributed throughout the country (DGPA, 2015). More than one third of the country's agricultural land is devoted to olive growing. The cultivation of the olive tree is spread from the North to the South, in varying bioclimatic conditions, with a great varietal diversity. Tunisia thus occupies the fourth position in the world in number of trees and the second largest in regard with the olive trees' cultivated area. At the national level, it contributes to the achievement of national objectives of food 
security, preserving natural resources and limiting rural exodus. Internationally, it gives Tunisia the rank of the fourth largest producer and third largest exporter of olive oil.

Several studies and experimental research have established that traditional Mediterranean diet is a source of good health (Keys, 1995), whereas the positive effect is linked to a main component of this diet, which is the olive and its derivatives. The fruit contain an important source of phenolic and antioxidant compounds. The derivate products have natural antioxidant properties, which intervene in the prevention and treatment of cancer, inflammatory and cardiovascular diseases. They are also used as additives for the food, pharmaceutical and cosmetic industries (Aouidi et al., 2007). The interest in phenolic compounds is extended to all olive products that can be consumed as foods, medicines, or that are generated as by-products of the olive industry such as leaves, wood and oils.

Olive trees are well adapted to abiotic stress (Zhang et al., 2011). The severity of climate caused biochemical changes in olive trees, such as the presence of secondary metabolites. These compounds played an important role in the plant response to environmental stress, having an important bioactivity against oxidative stress (Abaza et al., 2015). Recently, scientific research is increasingly interested in the leaves of olive tree, known for their richness in bioactive compounds such as vitamins, flavonoids and polyphenols. According to Aouidi et al. (2007), the highest percentage of total phenols is reserved for leaves, compared to other olive trees' organs, with a percentage of $35 \%$. Olive leaves have interesting antimicrobial and antioxidant activities and can be used as a natural and functional ingredient in food technology (Taamalli et al., 2012).

Moreover, several abiotic and biotic factors may be involved in the quantitative and qualitative variation of the various biochemical compounds of the olive tree. The climatic conditions exert the most significant effects, generated by a gradual restriction of rainfall and a continuous rise in temperature (Brahmi et al., 2012). Nevertheless, the antioxidant compounds, especially in the olive tree, are very sensitive to changes of climatic factors, which are increasing from day to day, resulting in significant global warming. Environmental stresses, especially the severity of climatic factors, significantly modify the metabolism of polyphenols, as well as the concentration of secoiridoids in olive trees (Petridis et al., 2012). The olive tree responds with the regulation of antioxidants synthesis to oppose stress.

The aim of the current work was to determine the total phenol, flavonoid, o-diphenols, tanin, chlorophyll, carotenoids, phytosterols and saponin contents in methanol extracts from 'Meski' olive cultivar leaves, collected within different climatic conditions. In addition, the antioxidative properties of the same cultivar in different bioclimatic levels were evaluated by DPPH and ABTS ${ }^{+}$radical-scavenging assays, in an attempt to establish the response and the adaptation of the olive cultivar against the severity of climate.

\section{Materials and Methods}

\section{Plant material}

Fresh leaves of 'Meski' cultivar were collected from three coastal zones of Tunisia: in Morneg $\left(36^{\circ}\right.$ $40^{\prime} 51^{\prime \prime}$ North; $\left.10^{\circ} 1725^{\prime \prime} \mathrm{Est}\right)$, Chott Mariem ( $\left.35^{\circ} 56^{\prime} 08^{\prime \prime} \mathrm{N} ; 10^{\circ} 33^{\prime} 26^{\prime \prime} \mathrm{E}\right)$ and Zarzis $\left(33^{\circ} 30^{\prime} \mathrm{N} ; 11^{\circ} 07^{\prime} \mathrm{E}\right)$ (Figure 1). Sampling was realized from different branches from twelve olive trees, about thirty years old. These samples were selected according to four orientations of the trees (North, East, South and West). 'Meski' cultivar has been grown on extensive, rainfall farming, in orchards characterized with densities up to 100 trees/ha. The relative humidity, the temperature and the precipitation of the studied areas were estimated from a standard meteorological station adjacent to the experimental field (Figure 2).

\section{Preparation of leaf extracts}

After harvest, the leaves were washed well with distilled water and air-dried at room temperature and in the shade. After grinding, the vegetable powder was stored away from light and humidity until extraction. The 
438

$5 \mathrm{~g}$ of sample dry weight was soaked in $50 \mathrm{~mL}$ of distilled water and left at room temperature, with stirring for 2 days. Thus, it is the hydraulic maceration that has been adopted to prepare the aqueous extract.

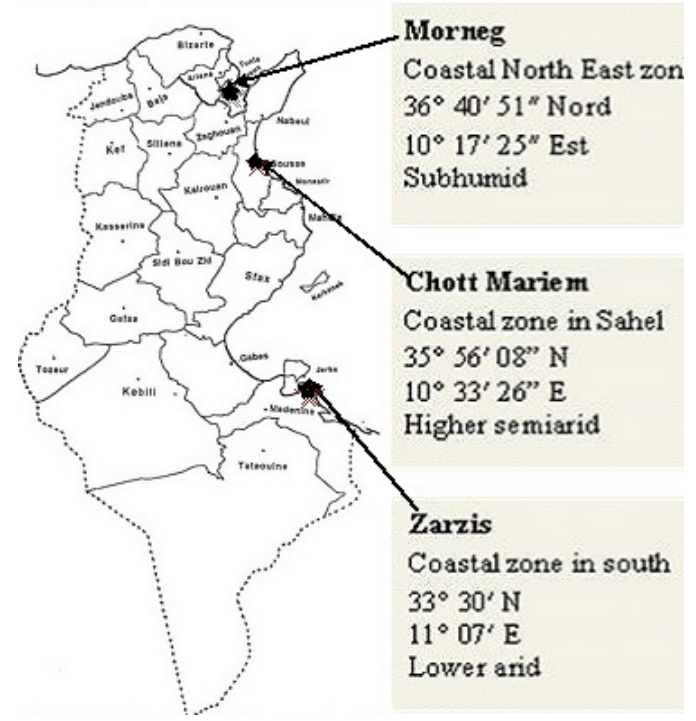

Figure 1. Description of three Tunisian growing areas of olive cv. 'Meski' Plant collected zones are shown in asterisk

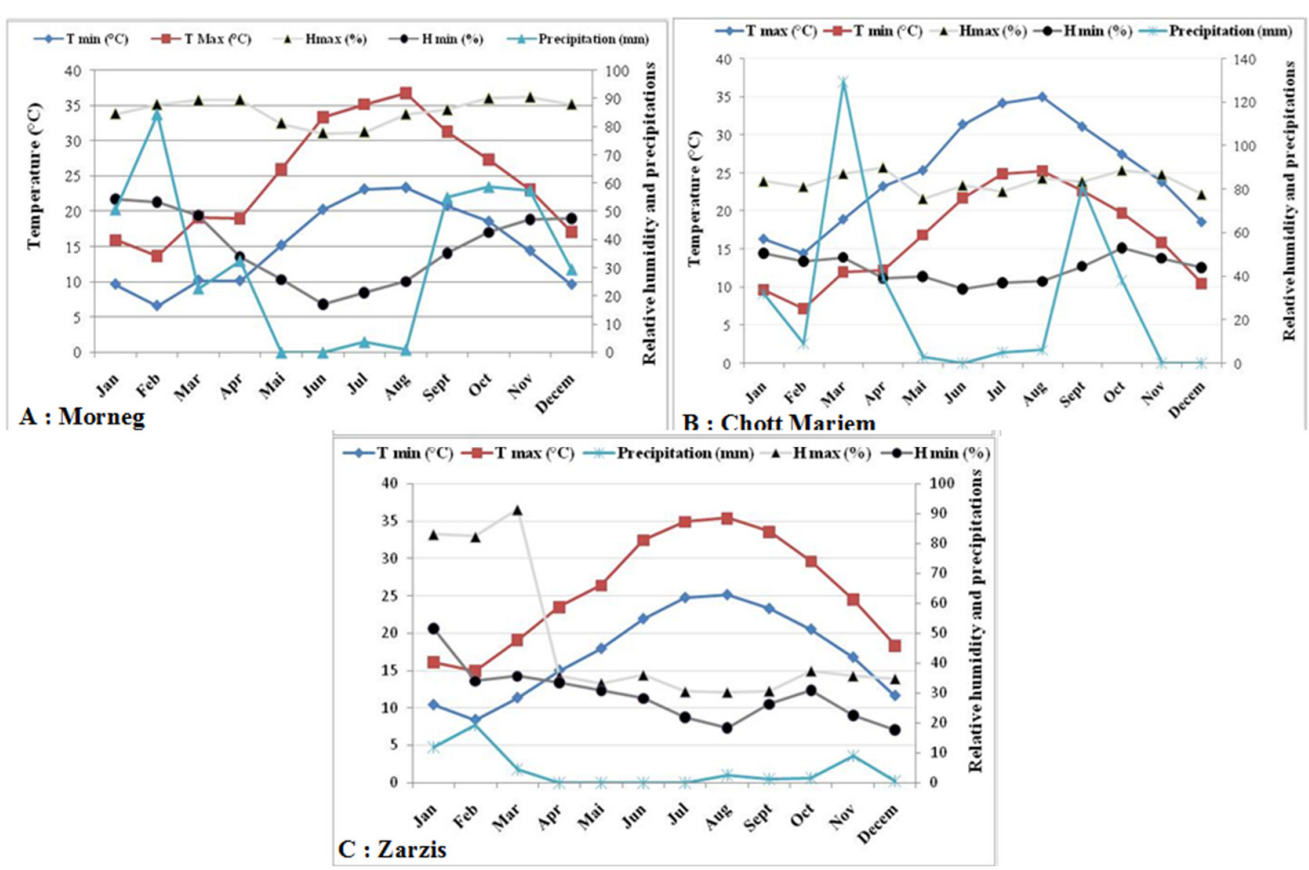

Figure 2. Monthly average of temperature, relative humidity and precipitations of three Tunisian studied areas during the culture 2012 of Olive tree Meski (Tmax: Maximal Temperature; Tmin: Minimal Temperature and HR: Relative Humidity)

In order to carry out analyzes of the phenolic compounds by colorimetric and chromatographic methods, the methanolic extract was prepared by mixing the dried aqueous extracts in methanol, and stirring for 24 hours. Then, a series of filtrations were carried out before drying by a rotary evaporator. 
Determination of secondary metabolites content

Determination of total phenols

Total phenolic content of the methanolic extracts was spectrometrically analyzed at $725 \mathrm{~nm}$ using the modified method designed by Ryan et al. (1999). The concentration of total polyphenols was estimated with Folin-Ciocalteau reagent. To $100 \mu \mathrm{L}$ of each sample extract suitably diluted, $750 \mu \mathrm{L}$ of Folin-Ciocalteu reagent and $100 \mu \mathrm{L}$ of di-ionized water were added. The mixture was shaken, added with $750 \mu \mathrm{L}$ of $\mathrm{Na}_{2} \mathrm{CO}_{3}(6 \%$, w/v) and adjusted with distilled water to a final volume of $3 \mathrm{~mL}$. After incubation in darkness for $90 \mathrm{~min}$ at $23^{\circ} \mathrm{C}$, the absorbance versus prepared blank was recorded at 725 $\mathrm{nm}$. The total phenolic compound (TPC) was expressed as milligram cathechin equivalents per gram of dry weight $\left(\mathrm{mg} \mathrm{CE} \cdot \mathrm{g}^{-1} \mathrm{DW}\right)$ cathechin using a calibration curve with $\left(10-50 \mu \mathrm{g} \cdot \mathrm{mL}^{-1}\right)$.

\section{Determination of total flavonoids}

Total flavonoids of the dry 'Meski' leaves extracts was spectrophotometrically determined by the aluminum chloride method, using quercetin as standard, as performed by the method of Dehpeur et al. (2009). One $\mathrm{ml}$ of properly diluted leaves' extract was mixed with $4 \mathrm{~mL}$ of distilled water. Then, $0.3 \mathrm{~mL}$ of $\mathrm{NaNO} 2(5 \%$, w/v) were added. After five minutes, $0.3 \mathrm{~mL}$ of $(10 \%$, w/v) $\mathrm{AlCl} 3$ and $2 \mathrm{~mL}$ of $\mathrm{NaOH}$ $(1 \mathrm{M})$ were added. Finally, the volume was immediately made up to $10 \mathrm{ml}$, by the addition of $2.4 \mathrm{ml}$ of distilled water. After 30 min incubation at darkness in room temperature, the absorbance of samples was measured at $430 \mathrm{~nm}$. The results were expressed as $\mathrm{mg}$ quercetin equivalents $(\mathrm{QE}) / \mathrm{g}$ dry weight. The values were calculated using the following equation: $Y=0.035 x+0.288$ with $R^{2}=0.995$. Samples were analyzed in triplicates.

\section{Determination of condensed tannins}

The condensed tannins are determined using the acidic vanillin method described by Ba et al. (2010). The method is based on the ability of vanillin to react with units of condensed tannins in the presence of an acid- hydrogen chloride, to produce a slightly coloured complex, measured at $510 \mathrm{~nm}$. The vanillin reagent was prepared by mixing equal volume: $8 \%(\mathrm{v} / \mathrm{v}) \mathrm{HCI}, 37 \%(\mathrm{v} / \mathrm{v})$ methanol and $4 \%$ vanillin in methanol $(\mathrm{w} / \mathrm{v}) .200 \mathrm{~mL}$ of each extract were added to $1,000 \mathrm{~mL}$ of vanillin reagent; the mixture was stirred and then incubated in the dark at $30^{\circ} \mathrm{C}$ for $20 \mathrm{~min}$. The absorbance was measured at $510 \mathrm{~nm}$ by a UV spectrophotometer (JENWAY 6400) against a blank consisting of a mixture of methanol (37\%) and $\mathrm{HCl}(8 \%)$ at equal volume. The results are expressed in mg catechin equivalents/g of dry weight with reference to the catechin calibration curve as follows:

$\mathrm{Y}=0.0053 \mathrm{x}+0.0075$ with $\mathrm{R}^{2}=0.9993$.

\section{Determination of o-diphenols}

The total content of the plant extract in diphenol was estimated by the method of Blekas et al. (2002), thus the determination of the extract with a solution of sodium molybdate (catalyst) in an acid and in the presence of phosphate buffer. After incubating at room temperature, the solution was analysed at $350 \mathrm{~nm}$ in UV-visible spectrophotometer. Caffeic acid was used to prepare a standard range in the concentration range of 0 to $100 \mathrm{mg}$. $\mathrm{L}^{-1}$.

\section{Determination of pigment content}

The methanolic extract of each sample was determined by UV spectrophotometer and the absorbances were read at 400-700 $\mathrm{nm}$. It was recorded that chlorophyll $a$ showed the maximum absorbance at $662 \mathrm{~nm}$, chlorophyll $b$ at $646 \mathrm{~nm}$ and total carotenoids at $470 \mathrm{~nm}$, whereas the amount of these pigments were calculated according to Lichtenthaler and Buschmann (2001):

$\mathrm{Ca}=15,65 \mathrm{~A}_{666}-7,340 \mathrm{~A}_{653}$ 
440

$$
\begin{aligned}
\mathrm{Cb}=27,05 \mathrm{~A}_{653}-11,21 \mathrm{~A}_{666} \\
\mathrm{C}_{\mathrm{x}+\mathrm{c}}=1000 \mathrm{~A}_{470}-2,860 \mathrm{Ca}-129,2 \mathrm{Cb} / 245
\end{aligned}
$$

Chlorophyll $a, b$ and carotenoids contents were expresses in $\mathrm{mg}^{-1}{ }^{-1}$ of weight extract.

\section{Determination of saponin}

The total saponin content in methanol extract was assayed according to the method described by Baccou et al. (1977). The standard solutions of dioscin were prepared, at the concentration $10.35 \mathrm{mg}$ in $50 \mathrm{~mL}$ of methanol, to produce the reference dioscin. For the calibration curve, 0.2, 0.3, 0.4, 0.5, 0.6, 0.8 and $0.9 \mathrm{~mL}$ standard solutions were individually added into one tube. Then, in the test tube, $200 \mu \mathrm{l}$ of $5 \%$ vanillin and 800 $\mu \mathrm{L}$ of perchloric acid were added. Afterward, this tube was placed in a water bath maintained at $60{ }^{\circ} \mathrm{C}$ for 20 min and then allowed to cool in $0{ }^{\circ} \mathrm{C}$ water bath, after which $5 \mathrm{ml}$ glacial acetic acid were added. The absorbance of the solution was measured at $457 \mathrm{~nm}$ by using a UV-visible spectrophotometer. An amount of $200 \mu \mathrm{L}$ of sample extract, at the concentration of $50 \mathrm{mg} \cdot \mathrm{mL}^{-1}$, was used. The results were expressed in mg Dioscine equivalent/g of extract.

\section{Determination of steroids}

The determination of phytosterols was based on the direct contact of the plant extract and the Liebermann-Burchard (LB) reagent (Araújoa et al., 2013). The latter is a mixture of three strong acids: glacial acetic acid, sulfuric acid and cold anhydride acetic. The $\beta$-Sitosterol was used as a standard, with a concentration of 0.02 to $0.1 \mathrm{mg} \cdot \mathrm{mL}^{-1}$. The mixture contains 200 of the extract and $5 \mu \mathrm{L}$ of $\mathrm{LB}$, was read in UV-visible spectrophotometer at $625 \mathrm{~nm}$.

\section{Determination of antioxidant activity}

The determination of antioxidant capacity of the methanolic extracts was tested by DPPH radical scavenging and ABTS radical cation assays as follows.

\section{DPPH radical-scavenging assay}

The antioxidant activity of 'Meski' leaves methanolic extracts was measured according to the method of Choi et al. (2002). The method is based on the radical scavenging ability against DPPH (2,2-diphenyl-2picrylhydrazyl hydrate). Samples of methanol extracts $(0.5 \mathrm{~mL})$ with different concentrations $(1,000 ; 250$; 62.5; 3.906 and $0.976 \mu \mathrm{g} / \mathrm{mL})$ were added to $0.5 \mathrm{~mL}$ of a DPPH methanolic solution $(60 \mu \mathrm{M})$. After stirring vigorously, the mixture was left standing in the dark at room temperature for $30 \mathrm{~min}$. The absorbance was read at $520 \mathrm{~nm}$ using ethanol as blank. $0.5 \mathrm{~mL}$ of DPPH solution mixed with $0.5 \mathrm{~mL}$ of ethanol was used as control. All the analyses were made in triplicate and total antioxidant activity was expressed as the percentage inhibition of the DPPH radicals scavenging rate and was determined as:

DPPH radical scavenging activity $(\%)=\left[1-\left(\mathrm{A}_{\text {sample }} / \mathrm{A}_{\text {control }}\right)\right] \times 100$

Where $\mathrm{A}_{\text {control }}$ is the absorbance of the control after $30 \mathrm{mn}$ (containing all reagents except the extract compound), $A_{\text {sample }}$ is the absorbance of the tested sample after $30 \mathrm{mn}$.

The actual decrease in absorbance induced by the tested sample (change of colour from deep-violet to light yellow) was compared to that of the positive control trolox. TEAC (Trolox equivalent antioxidant capacity) was determined as the amount of Trolox equivalent to the amount of test substance that resulted in $50 \%$ scavenging of DPPH radicals.

The IC50 values represent the concentration $\left(\mathrm{mg} \mathrm{mL}^{-1}\right)$ of sample which is required to scavenge $50 \%$ of DPPH free radicals.

Experiments were carried out in triplicate and the mean value was recorded. 
ABTS $\bullet$ radical assay

The evaluation of antioxidant activity for tested extracts was based on the $\mathrm{ABTS}^{\bullet+}$ free radical decolorization assay according to the method of Yu et al. (2002). The ABTS ${ }^{\bullet+}$ is widely used to assess the total amount of radicals that can be scavenged by an antioxidant capacity. Radical cation was prepared by oxidizing $100 \mu \mathrm{L}$ of ABTS commercial solution with $0.1 \mathrm{mg}$ of $\mathrm{K}_{2} \mathrm{~S}_{2} \mathrm{O}_{8}$. The mixture was diluted in $100 \mathrm{~mL}$ of di-ionised water and incubated in the dark at room temperature for $24 \mathrm{~h}$. Samples were diluted in ethanol at different concentration $\left(1,000 ; 250 ; 62.5 ; 3.906\right.$ and $\left.0.976 \mu \mathrm{g} . \mathrm{mL}^{-1}\right)$. The volume of $10 \mu \mathrm{L}$ of ethanolic fractions of 'Meski' leaves were added, at different concentrations, to $990 \mu \mathrm{L} \mathrm{ABTS}{ }^{\bullet+}$ solution and the absorbance was noted after $5,10,15,20$ and 30 min of initial mixing, at room temperature.

The absorbance of all samples was compared to that of the calibrated Trolox (TE) standard. The free radicalscavenging activity of each extract was measured in terms of Trolox equivalent antioxidant capacity (TEAC) as described by Re et al. (1999), measured after $30 \mathrm{~min}$ of the beginning of the reaction and the results were expressed as percent of inhibition. All experiments were carried out in triplicate. In fact, TEAC analysis is widely used to estimate the number of radicals inhibited by an antiradical (Arts et al., 2004).

\section{Results and Discussion}

\section{Total phenols and o-diphenols contents}

The determination of total phenols content (TPC) in leaves' methanolic extracts (Figure 3) revealed a significant difference between studies areas. The means of TPC in olive leaf extracts in terms of $\mathrm{mg}$ (cathechin equivalent) CE. $\mathrm{g}^{-1}$ Dry Weight (DW) were $1.45 \pm 0.0,2.73 \pm 0.01$ and $2.97 \pm 0.03 \mathrm{mg} \mathrm{CE} . \mathrm{g}^{-1} \mathrm{DW}$ for Northern, Center and Southern 'Meski' olive leaves respectively. In fact, 'Meski' leaves growing in the South and in the Center seemed to be the richest in phenolic compounds, contrarily to the Northern ones, which presented the lowest levels. These results were in accordance with the report of Brahmi et al. (2012), who showed, for the methanolic extract of Nebjmel, a seasonal change in the total phenol content between 3.51 and $2.50 \mathrm{mg} \cdot \mathrm{g}^{-1} \mathrm{DW}$ from leaves collected in October and February respectively.

The analysis of o-diphenols content in leaves extracts of cv. 'Meski' showed a significant difference between studied aeres (Figure 3B). The concentration of o-diphenols in 'Meski' leaves changed depending on the origin of samples and collected area. In fact, the highest level of this compound was found in extracts obtained from leaves collected in the Center of Tunisia $\left(2.09 \pm 0.40 \mathrm{mg.g}^{-1} \mathrm{DW}\right)$. However, Northern leaves showed the lowest contents such as $1.26 \pm 0.12 \mathrm{mg} \cdot \mathrm{g}^{-1} \mathrm{DW}$. Phenolic compounds, such as phenols and odiphenols in plants constitute a major class of secondary plant metabolites with bioactive potential attributed to antioxidant activity (Brahmi et al., 2012). Other studies report high polyphenolic content in extracts which was associated with antioxidant activity (Turkoglu et al., 2007). Thus, to protect against oxidative stress, procured by harsh weather conditions, 'Meski' olive tree improved phenolic content in their leaves.

\section{Flavonoid contents}

Flavonoids are one of the most important natural phenolic compounds (Shimoi et al., 1996). Total flavonoid contents of different extracts from olive leaves (Figure 4.) showed a significant difference between the studied areas. Therefore, these levels varied considerably, from $0.023 \pm 0.00$ to $0.673 \pm 0.00{\mathrm{mg} . \mathrm{g}^{-1} \mathrm{DW}}^{-1}$ respectively for the Northern, central and Southern 'Meski' leaves. The obtained results agree with Brahmi $e t$ al. (2012), who reported that the total flavonoids content in leaves extracts of Nebjmel varied with the season and the solvent extract. Also, Zeitoun et al. (2017) showed that flavonoids content of olive leaves ranged from $0.057 \pm 0.006$ to $0.125 \pm 0.003 \mathrm{mg} . \mathrm{g}^{-1}$. The leaves extracts obtained from Southern area registered the highest level of total flavonoids. In fact, leaves in Southern area were twenty time richer in flavonoids than the 
442

Northern ones. The increase of this antioxidant could be attributed to the severity of climate. In general, drought increased concentrations of antioxidants and photo protective pigments (Wujeska et al., 2013).
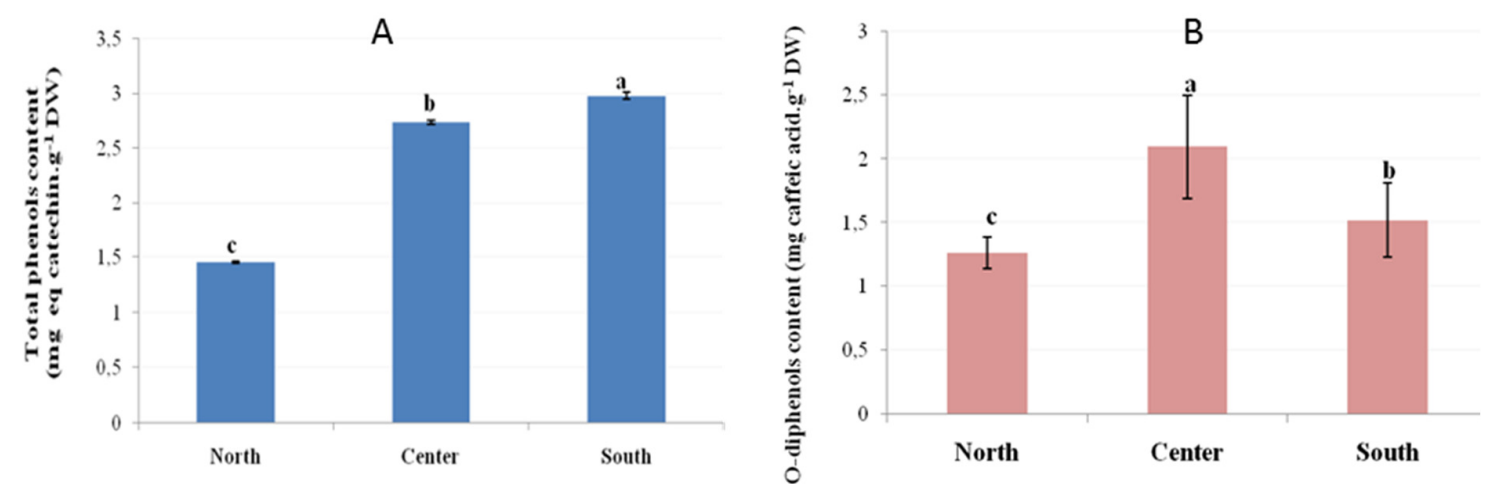

Figure 3. Total phenols (A) and o-diphenols contents (B) of extracts of olive leaves harvested at flowering. Results are expressed as cathechin and caffeic acid equivalents respectively for total phenols and odiphenols. Values are expressed as means \pm standard deviation $(n=3)$. Means with different letters were significantly different at the level of $\mathrm{p}<0.05$

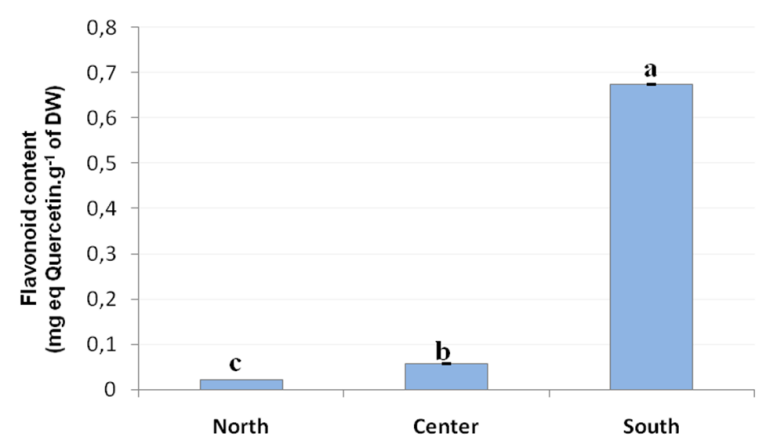

Figure 4. Total flavonoid contents of olive leaves harvested at flowering. Means with different letters were significantly different at the level of $\mathrm{p}<0.05$. Results are expressed as quercetin equivalents for total flavonoids in Center and Southern collected leaves, demonstrating their important role in adaptation to severe climatic conditions

Generally, drought increased the concentration of antioxidants (Wujeska et al., 2013). Some flavonoids provide stress protection, as scavengers of free radicals such as reactive oxygen species (ROS) (Falcone Ferreyra et al., 2012). These compounds could be considered as a marker of draught stress and adaptation.

\section{Condensed tannins content}

The condensed tannin values are expressed as means \pm standard deviation $(n=3)$. Means with different letters were significantly different at the level of $\mathrm{p}<0.05$.

Condensed tannins, oligomeric and polymeric proanthocyanidins are natural sources of organic compounds, widely used in medicinal and industrial application (Morales et al., 2017). According to the results obtained (Figure 5), leaves' extract showed a significant difference between the three areas. The extract of leaves collected from the South and the Center presented high condensed tannin content. In fact, the Southern $(0.84$ $\left.\pm 0.00 \mathrm{mg} \mathrm{EQ} \cdot \mathrm{g}^{-1} \mathrm{DW}\right)$ and the Center leaves $\left(0.74 \pm 1.36 \mathrm{mg} \mathrm{EQ} \cdot \mathrm{g}^{-1} \mathrm{DW}\right)$ registered the upmost level in condensed tannins, but the Northern ones $\left(0.24 \pm 0.00 \mathrm{mg} \mathrm{EQ.g^{-1 }} \mathrm{DW}\right)$ showed the lowest amount. Condensed tannins increased with the severity of climate, draught and high temperature. However, under favorable climates, in Northern area, the tannin concentrations in leaves tissues formed were lower. These 
results are in agreement with those of Top et al. (2017) who proved that the climate stress in Quercus ruba responded by producing a greater quantity of tannins. These phenolic compounds could be attributed to protect plants against environmental stresses (Agrawel et al., 2005; Top et al., 2017).

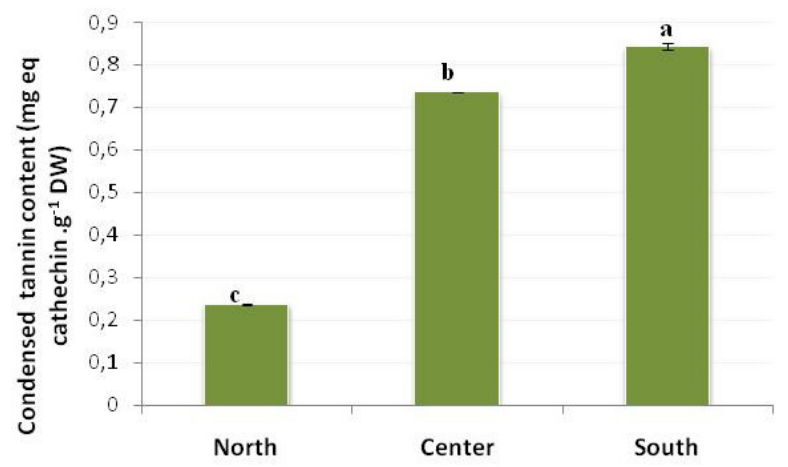

Figure 5. Condensed tannins contents of olive leaves extract collected from three different bioclimatic ranges of Tunisia. Values are expressed as means \pm standard deviation $(n=3)$. Means with different letters were significantly different at the level of $\mathrm{p}<0.05$

\section{Phytosterols content}

Sterols are isoprenoid-derived compounds, essential to the growth and development of eukaryotic organisms. Sterols are lipophilic membrane components essential for diverse cellular functions, such as cell division, cell elongation, cell polarity and cellulose accumulation (Boutté and Grebe, 2009). Results showed a significant difference between different areas studied hereby. In fact, according to Figure 6, the highest content of phytosterol content was present in Southern leaves (2.94 mg eq sitosterol. $\left.\mathrm{g}^{-1} \mathrm{DW}\right)$, followed by Center leaves $\left(0.79 \mathrm{mg}\right.$ eq sitosterol.g $\left.\mathrm{g}^{-1} \mathrm{DW}\right)$, whereas the Northern ones registered the lowest content $(0.22 \mathrm{mg}$ eq sitosterol.g $\left.\mathrm{g}^{-1} \mathrm{DW}\right)$. The increase of phytosterols with the severity of climate could be a response of olive tree to support draught stress and indicated the role of this compound in providing tolerance to stress (Kolo, 2016). The result was in agreement with those of Vrieta et al. (2013) and Ferrer et al. (2017) who reported that these sterols are involved in plant growth and development, as well as in plant responses to biotic and abiotic stresses. There are increasing evidences supporting the involvement of conjugated sterols in plant stress responses, whereas sterols play a prominent role in plant stress tolerance (Vrieta et al., 2013; Ferrer et al.,2017). The study of Kolo (2016) showed that the inhibition of phytosterols synthesis increased the reactive oxigen species content in maize leaves.

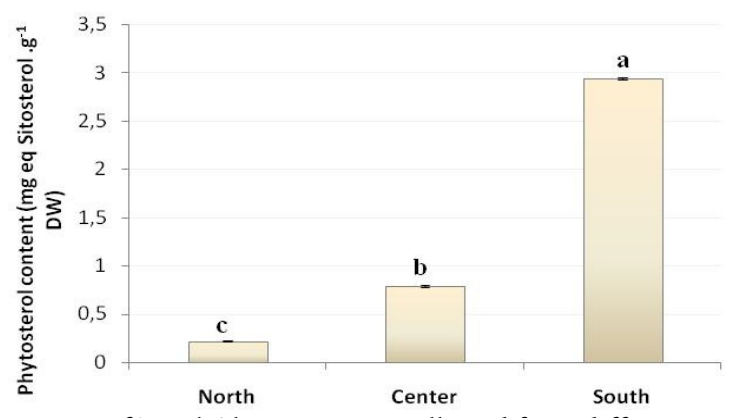

Figure 6. Phytosterol contents of 'Meski' leaves extract collected from different areas. Values are expressed as means \pm standard deviation $(\mathrm{n}=3)$. Means with different letters were significantly different (Duncan test, $\mathrm{p}<0.05$ )

Saponin content 
Saponins are natural phyto-chemicals and may be found in a wide variety of plants. Saponins are active ingredients in plants, consisting of a hydrophobic aglycone structure with hydrophilic sugar residues (Böttcher and Drusch, 2017). These properties are responsible for the interaction between saponins and cell membranes, attributes such as their anti-fungal activities (Madland, 2013), anti-oxidant, anti-virus, anti-inflammation and anti-cancer activities (Lv et al., 2013; Yu et al., 2014). These compounds have a promising application in medicine, agriculture, industry and environmental protection. The results obtained showed the effect of the region on saponin production in 'Meski' leaves and are presented in Figure 7. A significant difference between Northern, Central and Southern 'Meski' leaves saponin content was noted. Saponin content increased with the severity of climate. However, leaves collected from Southern areas (high temperature and draught) showed the highest saponin level $\left(0.87 \pm 0.00 \mathrm{mg}\right.$ eq diocin. $\left.\mathrm{g}^{-1} \mathrm{DW}\right)$, followed by the Center $(0.678 \pm 0.00 \mathrm{mg}$ eq diocin. $\mathrm{g}^{-1} \mathrm{DW}$ and the North $\left(0.42 \pm 0.00 \mathrm{mg}\right.$ eq diocin. $\left.\mathrm{g}^{-1} \mathrm{DW}\right)$. These results agreed with those of Odjegba and Alokolaro (2013) who reported that drought and salinity treatments enhanced saponin production in $A$. wilkesiana plants. Also, El-Sayed et al. (2008) reported that saponin content in Trubulus increased under water stress. The increase could be related to the protective role against oxidative stress (Lin et al., 2009).

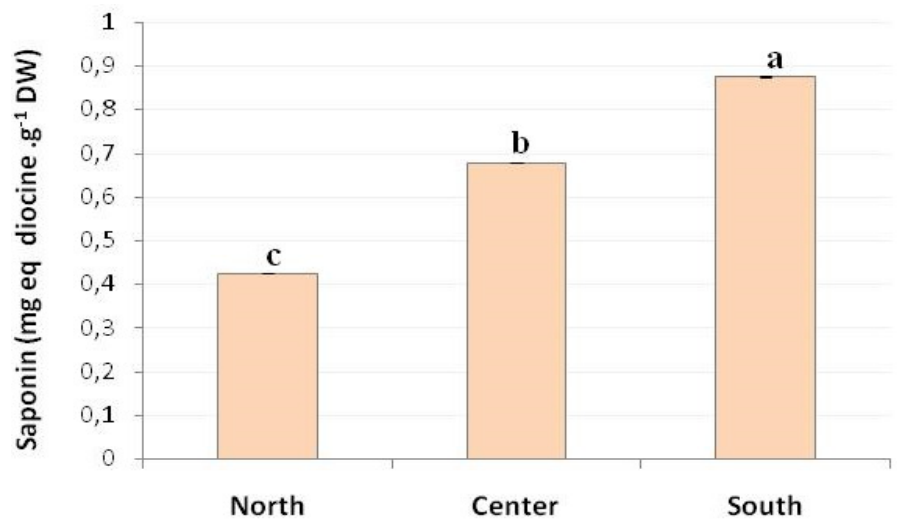

Figure 7. Saponin contents in leaves extract of 'Meski' collected from different areas. Values are expressed in mg equivalent diocine per gram of the plant extract, as means \pm standard deviation $(n=3)$. Means with different letters were significantly different at the level of $\mathrm{p}<0.05$

\section{Pigment content}

The analysis of pigments' content in the leaves showed significant differences between studied areas. The concentration of chlorophyll $a$, chlorophyll $b$, total chlorophyll and total carotenoids were influenced by climatic conditions (Figure 8). The highest chlorophyll levels were registered in Northern 'Meski' leaves, but the lowest was occurred in Southern ones (total chlorophyll content was 225.80 $\pm 22.54,149.10 \pm 6.32$ and $77.67 \pm 0.59 \mathrm{mg} \cdot \mathrm{g}^{-1} \mathrm{DW}$ respectively for Northern, Center and Southern leaves). Chlorophyll $a, b$ and total chlorophyll levels decreased with the severity of climate, such as the increase of temperature and draught. The results were in accordance with those of Hanci and Cebeci (2014) and Arji and Arzani (2008) who proved that under drought stress conditions, the amount of chlorophyll $a$ and $b$ in olive cultivars decreased significantly. Indeed, drought is one of the factors affecting photosynthesis and chlorophyll content (Khaleghi et al., 2012).

Carotenoids content in leaves extract increased with the severity of climate from the North to the South. In fact, the amount of carotenoids in Southern leaves extracts $\left(122.80 \pm 0.02 \mathrm{mg}^{-1} \mathrm{~g}^{-1} \mathrm{DW}\right)$ was higher than that in the Northern ones $\left(4.94 \pm 0.65 \mathrm{mg} \cdot \mathrm{g}^{-1} \mathrm{DW}\right)$. The significant increase in content of carotenoids in the studied cultivar under severe climate suggested that Southern olive leaves provided stronger photo protective system against oxidative stress caused by drought stress (Hanci and Cebeci, 2014). Also, Wujeska et al. (2013) attributed the increase of the concentration of antioxidants with progressing stress, as a strengthening of defense systems and therefore an indication of acclimation to stress. Some researchers reported that carotenoids 
had an antioxidant property against oxidative stress. Therefore, maintenance of higher levels of the antioxidants can be a good strategy of plants to counter the negative effects of reactive oxygen species (Sharma and Dubey, 2005) by preventing chlorophyll-photosensitized formation of ${ }^{1} \mathrm{O} 2$ by intercepting the chlorophyll triplet states (Demmig-Adams and Adams, 1996).

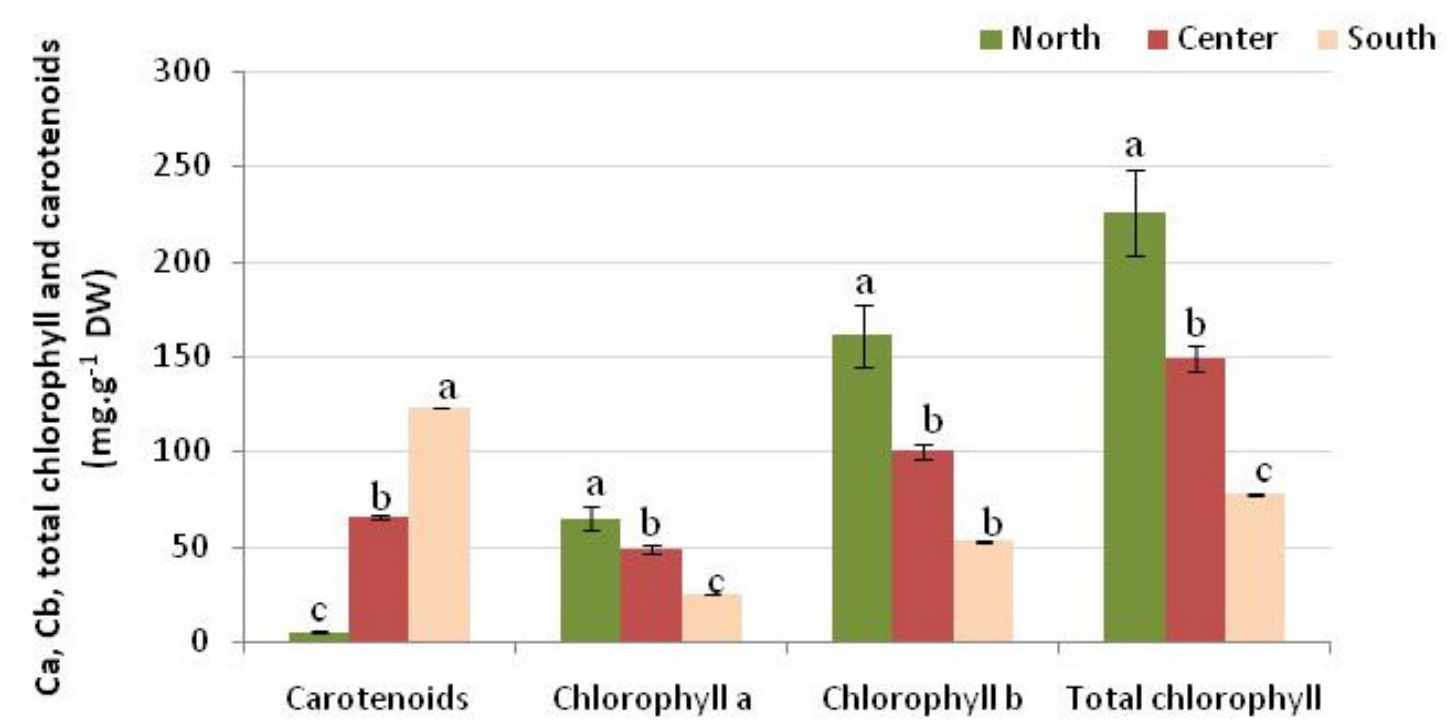

Figure 8. Total pigment content of the olive leaves sampled from cultivar 'Meski' harvested at flowering from different areas. Mean composition of sampled leaf tissue from three replications of three individual samples (three plants each) \pm standard deviation

\section{Antioxidants capacity of olive leaves}

The capacity of olive leaves extracts, collected from different areas, to scavenging free radicals have been evaluated applying DPPH and $\mathrm{ABTS}^{\bullet+}$ radicals.

\section{Radical-scavenging activities on DPPH}

The DPPH is a stable free radical. It accepts an electron or hydrogen radical to become a stable molecule and is reduced in the presence of an antioxidant (Choi, 2002). The evaluation of the antioxidants activities of 'Meski' leaves from Northern, Central and Southern areas were expressed in inhibition percentage and the results are established in Table 1.

The antioxidant in all investigated samples seemed to be proportional to the concentration of the extract. The antioxidant activity of 'Meski' leaves is very important, reaching up to $95.26 \%$ for the central areas at a concentration of $1,000 \mu \mathrm{g} \cdot \mathrm{mL}^{-1}$ and $76.58 \%$ for the Southern ones. Indeed, over than $62.5 \mu \mathrm{g} \cdot \mathrm{mL}^{-1}$ concentration, methanolic extracts of the Center area showed the highest antioxidant activity up to $83 \%$ against DPPH radicals. Meanwhile, at low concentration $\left(0.976 \mu \mathrm{g} \cdot \mathrm{mL}^{-1}\right)$ Southern leaves extract showed the most antioxidant activity against DPPH radicals (59.32 $\pm 0.68 \%)$. Indeed, above $62.5 \mu \mathrm{g} \cdot \mathrm{mL}^{-1}$ concentrations, the inhibition percentage of tested extracts was lesser than that of Trolox, but for the lower ones $(15.62 ; 3.976$ and $\left.0.976 \mathrm{~g} . \mathrm{mL}^{-1}\right)$, the inhibition of these extracts exceeds it, thus showing a better efficiency of these extracts to scavenging free radicals at low levels.

Table 1. Free radical-scavenging capacities of olive leaves extracts, Trolox and IC 50 measured in DPPH assay 
Ben Mansour-Gueddes S et al. (2020). Not Bot Horti Agrobo 48(1):436-455

446

\begin{tabular}{|c|c|c|c|c|c|c|c|c|}
\hline $\begin{array}{c}\text { Concentrations } \\
\left(\mu \mathrm{g} . \mathrm{mL}^{-1}\right)\end{array}$ & 1,000 & 250 & 62.5 & 15.625 & 3.906 & 0.976 & $\begin{array}{c}\text { IC50 } \\
\left(\mu \mathrm{g} \cdot \mathrm{mL}^{-1}\right)\end{array}$ \\
\hline \multicolumn{7}{|c|}{ Inhibition percentage (\%) } \\
\hline North & $66.04 \pm 0.44$ & $\begin{array}{c}73.18 \pm \\
4.51\end{array}$ & $\begin{array}{c}52.22 \pm \\
2.75\end{array}$ & $\begin{array}{c}39.06 \pm \\
1.40\end{array}$ & $\begin{array}{c}40.1 \pm \\
3.90\end{array}$ & $\begin{array}{c}40.88 \\
\pm 7.20\end{array}$ & $50.7 \pm 0.01$ \\
\hline Center & $95.27 \pm 0.00$ & $\begin{array}{c}92.77 \pm \\
1.12\end{array}$ & $\begin{array}{c}83.77 \pm \\
14.33\end{array}$ & $\begin{array}{c}51.76 \pm \\
1.62\end{array}$ & $\begin{array}{c}47.15 \pm \\
9.03\end{array}$ & $\begin{array}{c}43.75 \\
\pm 3.64\end{array}$ & $12.3 \pm 0.04$ \\
\hline South & $76.59 \pm 4.84$ & $\begin{array}{c}84.35 \pm \\
6.45\end{array}$ & $\begin{array}{c}79.99 \pm \\
2.69\end{array}$ & $\begin{array}{c}68.04 \pm \\
1.13\end{array}$ & $\begin{array}{c}58.61 \pm \\
2.70\end{array}$ & $\begin{array}{c}59.32 \\
\pm 0.68\end{array}$ & $0.6 \pm 0.02$ \\
\hline Trolox & $99.37 \pm 0.01$ & $\begin{array}{c}99.37 \pm \\
0.50\end{array}$ & $\begin{array}{c}99.71 \pm \\
1.10\end{array}$ & $\begin{array}{c}32.05 \pm \\
0.70\end{array}$ & $\begin{array}{c}9.98 \pm \\
0.91\end{array}$ & $\begin{array}{c}3.56 \pm \\
0.35\end{array}$ & $24.5 \pm 0.01$ \\
\hline
\end{tabular}

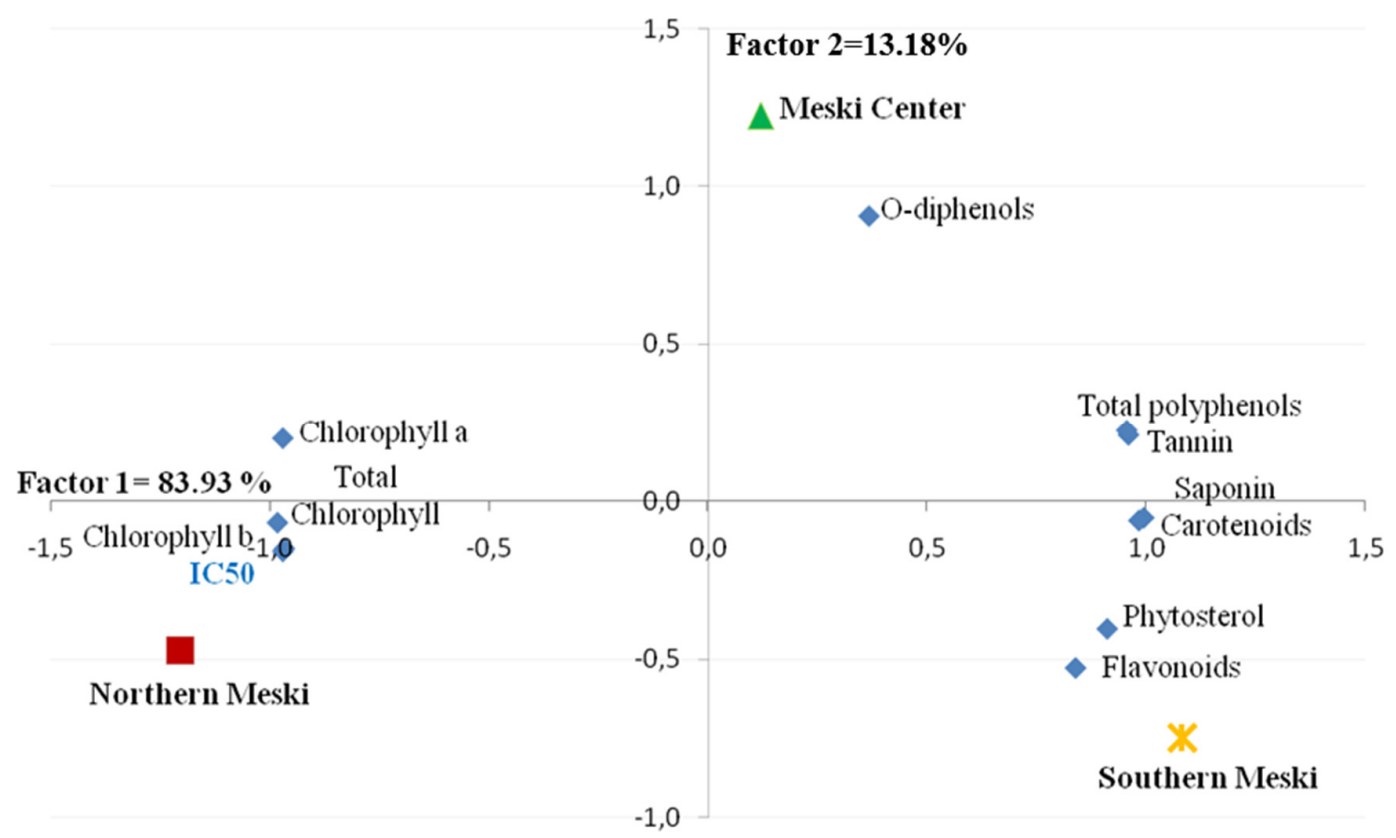

Figure 9. Principal component analysis of the main groups of phenolic compounds, pigment content, saponin, phytosterol in 'Meski' leaves from different areas (North, Center and South of Tunisia). Factors 1 and 2 explain $97.11 \%$ of the data variation

In the three studied areas leaves extracts have shown important scavenging activities on DPPH radicals. Furthermore, the Southern and the Center leaves extract registered higher antioxidant activities than the Northern ones $\left(\mathrm{IC} 50=50.7 \mu \mathrm{g} \cdot \mathrm{mL}^{-1}\right)$. The lowest IC50 was represented by Southern leaf extract, $0.6 \pm 0.02$ $\mu \mathrm{g} \cdot \mathrm{mL}^{-1}$ suggesting a high antioxidant capacity of these leaves to neutralize free radicals. The results were lower than those of Zeitoun et al. (2017) and Thalhaoui et al. (2016) who fined in dried leaves IC50 values of 427.00 $\pm 23.5 \mu \mathrm{g} \cdot \mathrm{mL}^{-1}$ and $129.9 \pm 23.5 \mu \mathrm{g} \cdot \mathrm{mL}^{-1}$ respectively. Furthermore, the hereby obtained results were in accordance with those of Boubakri et al. (2017), who explained that the IC50 were $44.83 \pm 0.35 \mu \mathrm{g} \cdot \mathrm{mL}^{-1}$ and $58.08 \pm 3.5 \mu \mathrm{g} \cdot \mathrm{mL}^{-1}$ of Swihli and Rihane extracts respectively.

According to the results presented in Table 1 , Southern (IC50 $=0.6 \pm 0.02 \mu \mathrm{g} \cdot \mathrm{mL}^{-1}$ ) and Center (IC50 $\left.=12.3 \pm 0.04 \mu \mathrm{g} \cdot \mathrm{mL}^{-1}\right)$ leaves extracts were characterized by a higher free radicals scavenging property in comparison to that of synthetic antioxidant Trolox $\left(\mathrm{IC} 50=24.5 \mu \mathrm{g} . \mathrm{mL}^{-1}\right)$. According to Zeitoun et al. (2017) antioxidant molecules such as phenolic compounds, flavonoids, tannins, carotenoids and phytosterols, which play part in the antioxidant system as non-enzymatic components, reduce and decolorize DPPH due to their hydrogen donating ability. 
Therefore, maintenance of the higher levels of the antioxidants can be a good strategy by the plants to counter the negative effects of ROS generated by draught and high temperature (Sharma and Dubey, 2005).

\section{ABTS ${ }^{\bullet+}$ scavenging assay}

The evaluation of ABTS radical cation scavenging capacity of the tested extracts were expressed as percentages of free radical inhibitions as function of time (Table 2).

The potential antioxidant of the extract of different leaves showed consistent variability among different studied areas. Also, the samples depended strongly with the duration of the reaction and the concentration of the extract.

Table 2. $\mathrm{ABTS}^{\bullet+}$ cation radical scavenging capacity (\%) of methanolic extracts of cv. 'Meski' leaves collected from the North, the Center and the South of Tunisia, as a function of time and concentrations

\begin{tabular}{|c|c|c|c|c|c|c|c|}
\hline Origins & Incubation time & $\mu \mathrm{g} . \mathrm{mL}^{-1}$ & $5 \mathrm{~min}$ & $10 \mathrm{~min}$ & $15 \mathrm{~min}$ & $20 \mathrm{~min}$ & $30 \mathrm{~min}$ \\
\hline \multirow{4}{*}{} & & 1,000 & $22.66 \pm 0.04$ & $19.37 \pm 0.02$ & $25.45 \pm 0.03$ & $23.96 \pm 0.05$ & $26.31 \pm 0.04$ \\
\cline { 2 - 8 } & & 250 & $22.21 \pm 0.01$ & $11.04 \pm 0.04$ & $12.39 \pm 0.03$ & $12.03 \pm 0.01$ & $14.82 \pm 0.03$ \\
\cline { 2 - 8 } & & 62.5 & $5.11 \pm 0.04$ & $5.50 \pm 0.01$ & $6.17 \pm 0.01$ & $6.89 \pm 0.02$ & $10.45 \pm 0.04$ \\
\cline { 2 - 8 } & & 15.62 & $4.34 \pm 0.04$ & $4.28 \pm 0.01$ & $6.53 \pm 0.01$ & $4.59 \pm 0.02$ & $10.95 \pm 0.02$ \\
\cline { 2 - 8 } & & 3.90 & $2.30 \pm 0.02$ & $6.49 \pm 0.01$ & $5.72 \pm 0.02$ & $7.16 \pm 0.01$ & $8.56 \pm 0.02$ \\
\cline { 2 - 8 } & & 0.97 & $3.69 \pm 0.02$ & $4.64 \pm 0.01$ & $4.37 \pm 0.08$ & $7.79 \pm 0.02$ & $7.84 \pm 0.01$ \\
\cline { 2 - 8 } & & 1000 & $35.24 \pm 0.05$ & $43.55 \pm 0.07$ & $43.50 \pm 0.08$ & $44.91 \pm 0.03$ & $51.50 \pm 0.08$ \\
\cline { 2 - 8 } & & 250 & $20.12 \pm 0.1$ & $22.03 \pm 0.01$ & $22.12 \pm 0.09$ & $22.30 \pm 0.04$ & $29.39 \pm 0.06$ \\
\cline { 2 - 8 } & & 62.5 & $19.62 \pm 0.01$ & $17.85 \pm 0.08$ & $11.85 \pm 0.03$ & $10.45 \pm 0.04$ & $26.17 \pm 0.12$ \\
\cline { 2 - 8 } & & 15.62 & $18.94 \pm 0.14$ & $18.03 \pm 0.13$ & $19.63 \pm 0.07$ & $19.99 \pm 0.06$ & $25.58 \pm 0.02$ \\
\cline { 2 - 8 } & & 3.90 & $18.48 \pm 0.04$ & $21.07 \pm 0.05$ & $22.52 \pm 0.07$ & $23.52 \pm 0.03$ & $24.61 \pm 0.06$ \\
\cline { 2 - 8 } & & 0.97 & $18.43 \pm 0.14$ & $19.39 \pm 0.04$ & $19.26 \pm 0.02$ & $20.99 \pm 0.02$ & $24.48 \pm 0.02$ \\
\cline { 2 - 8 } & & 1000 & $30.78 \pm 0.01$ & $30.29 \pm 0.02$ & $32.79 \pm 0.08$ & $38.70 \pm 0.04$ & $43.82 \pm 0.01$ \\
\cline { 2 - 8 } & & 250 & $14.67 \pm 0.02$ & $17.03 \pm 0.01$ & $19.17 \pm 0.04$ & $21.93 \pm 0.03$ & $29.79 \pm 0.08$ \\
\cline { 2 - 8 } & & 62.5 & $11.04 \pm 0.02$ & $10.49 \pm 0.01$ & $13.44 \pm 0.04$ & $20.44 \pm 0.08$ & $25.80 \pm 0.02$ \\
\cline { 2 - 8 } & & $7.90 \pm 0.01$ & $10.27 \pm 0.06$ & $13.26 \pm 0.02$ & $17.44 \pm 0.02$ & $21.44 \pm 0.07$ \\
\cline { 2 - 8 } & & 3.9 & $7.58 \pm 0.02$ & $8.08 \pm 0.01$ & $11.12 \pm 0.01$ & $16.71 \pm 0.1$ & $21.04 \pm 0.01$ \\
\cline { 2 - 8 } & & 0.97 & $7.35 \pm 0.02$ & $9.76 \pm 0.02$ & $10.12 \pm 0.07$ & $11.26 \pm 0.04$ & $20.67 \pm 0.01$ \\
\hline
\end{tabular}

The antioxidant activity increased as function of time and the extract concentrations. In fact, at 1,000 $\mu \mathrm{g} . \mathrm{mL}^{-1}$ after $30 \mathrm{~min}$ of contact with $\mathrm{ABTS}{ }^{\bullet+}$, 'Meski' leaves had a moderate antioxidant activity of about 51.50 $\pm 0.08,43.82 \pm 0.01$ and $26.31 \pm 0.04 \%$ for the Center, the Southern and the Northern leaves respectively. Indeed, at the same concentration and after $5 \mathrm{~min}$ of application only $22.66 \pm 0.04,35.24 \pm 0.05$ and $30.78 \pm$ $0.01 \%$ of radicals were scavenged from Northern, Center and Southern 'Meski' leaves respectively (Table 2).

At the same incubation time $(30 \mathrm{~min})$, the activity depended to the concentration of the extracts. In fact, the antioxidant activity seemed to increase according to the concentration, especially for the central areas where there was a significant increase, around $68 \%$.

For the lower concentrations, less than $250 \mu \mathrm{g} \cdot \mathrm{mL}^{-1}$ for all tested areas, leaves extracts exhibited a feeble scavenging efficiency toward ABTS cation radicals, from $2.30 \pm 0.02 \%$ to $29.79 \pm 0.08 \%$ for Northern and Southern leaves respectively. These results were in agreement with those of Brahmi et al. (2014) which indicated an important impact of the region on the antioxidant potential of leaves, stems and fruits of 'Chemchali' and 'Chetoui', while they suggested that olive leaves cultivated in the North of Tunisia contained higher antioxidant activity than the leaves from the South.

The TEAC is a measurement of the effective antioxidant activity of the fraction, whereas a higher TEAC would imply greater antioxidant activity of the sample. It was observed that methanolic fraction of Southern leaves had the highest TEAC of $0.94 \mathrm{mM}$, when applied at $1,000 \mu \mathrm{g} \cdot \mathrm{mL}^{-1}$ (Table 3). However, the TEAC values 
448

of the other fractions, at this concentration, ranged from 0.12 to $0.74 \mathrm{mM}$. After $30 \mathrm{~min}$ of the initiation reaction, the TEAC of all extracts was lower than $1 \mathrm{mM}$ (Table 3). So, the antioxidant activity of extracts of this variety is therefore lower than that of Trolox.

Table 3. Radical cation scavenging activity of leaves extracts expressed as Trolox equivalent after 30 min of incubation

\begin{tabular}{|c|c|c|c|c|c|c|}
\hline \multicolumn{7}{|c|}{ Concentrations $\left(\mu \mathrm{g} \cdot \mathrm{mL}^{-1}\right)$} \\
\hline TEAC & 1,000 & 250 & 62.5 & 15.62 & 3.9 & 0.97 \\
\hline North & 0.74 & 0.73 & 0.39 & 0.53 & 0.28 & 0.27 \\
\hline Center & 0.64 & 0.27 & 0.26 & 0.37 & 0.22 & 0.20 \\
\hline South & 0.94 & 0.52 & 0.12 & 0.44 & 0.73 & 0.56 \\
\hline
\end{tabular}

TEAC: Trolox Equivalent Antioxidant Capacity

For the free radicals $\mathrm{ABTS}^{\bullet+}{ }^{+}$, the antioxidant activity is less potent than that vis-à-vis DPPH, it reaches only a maximum of 51.49\%, for 'Meski' leaves collected from the center of the country area. Aruoma (2003) noted the need of using several methods to understand the antioxidant activity of the tested samples. Ozcelik et al. (2003) reported that DPPH absorbance at $517 \mathrm{~nm}$ decreased by light, oxygen, $\mathrm{pH}$ and type of solvent in addition to the antioxidant.

'Meski' constitute a drought-tolerant cultivar. To protect against oxidative stress induced by the severity of climate, 'Meski' leaves continuously activated the antioxidant defense systems in the plants (Panday et al., 2017). It should have a better antioxidant system to effectively prevent oxidative damage and neutralized radicals (Rout and Shaw, 2001). This activity could be attributed to the richness in bioactive compounds such as phenolic compounds which is involved in the protection against oxidative stress caused by environmental conditions (Grace, 2005).

\section{Correlation between bioactive compounds and antioxidant activity}

Pearson correlation ( $r$ ) was studied to determine the relationship between the potential antioxidant (IC50) and total polyphenol, O-diphenols, flavonoids, tannin, phytosterol, saponin and carotenoids levels of the extracts (Table 4). The antioxidant activity (IC50) was negatively and significantly correlated with total polyphenol $(\mathrm{r}=-0.997)$, flavonoids $(\mathrm{r}=-0.715)$, tannin $(\mathrm{r}=-0.998)$, phytosterol $(\mathrm{r}=-0.813)$, saponin $(\mathrm{r}=$ $0.974)$ and carotenoids $(\mathrm{r}=-0.924)$; whereas, chlorophyll pigments showed a positive and significant correlation, suggesting that the lower values of IC50 proved high antioxidant activities. Also, Table 4 showed a significant positive correlation between total polyphenol and tannin $(r=1)$, phytosterol $(r=0.76)$, saponin $(\mathrm{r}=0.95)$ and carotenoids $(\mathrm{r}=0.9)$. The data showed that these bioactive compounds contributed to increase the antioxidant activity. The study of Lee et al. (2009) showed a high correlation of the antioxidant activity with the amount of phenolic compounds and flavonoids in olive leaves. Many previous studies have reported significant correlation between polyphenolics and antioxidant activities in fruits, barley and mushrooms (Goupy et al., 1999; Leong and Shui, 2002; Choi and Wang, 2005). The observation agrees with other studies (Brahmi et al., 2012) which indicated that high polyphenolic content in extracts was significantly associated with antioxidant activity. Also, Kolo (2016) showed a relationship between sterol biosynthesis, sterol content, in maize leaves, and reactive oxygen species signalling.

The synergism between antioxidants (total polyphenol, flavonoids, tannin, phytosterol, saponin and carotenoids) could explain why the leaves' antioxidant capacity is higher than the individual content in each antioxidant. Similar results have been found in other researches (Thaipong et al., 2006; Silva and Sirasa, 2018).

Olive leaf extracts exhibited high antioxidant capacity which suggests olive leaf extract is effective in the function of scavenging free radicals (Luo et al., 2011). Olive leaves are a strong source of radical scavengers that are available throughout the year and all the types of leaves expected in an olive tree shoot can be exploited for the extraction of bioactive compounds, feasibly (Papoti and Tsimidou, 2009; Kolo, 2016). 
Table 4. Pearson's correlation coefficients among the main phenolic compounds, pigment content, phytosterol and the antioxidant activity of olive leaves from Northern, Center and Southern areas

\begin{tabular}{|c|c|c|c|c|c|c|c|c|c|c|c|}
\hline & $\begin{array}{c}\text { Total } \\
\text { phenol }\end{array}$ & $\begin{array}{c}\text { Flavon } \\
\text {-oids }\end{array}$ & $\begin{array}{l}\text { Tan- } \\
\text { nins }\end{array}$ & $\begin{array}{c}\text { O-diph- } \\
\text { enol }\end{array}$ & $\begin{array}{l}\text { Phytos } \\
\text {-terol }\end{array}$ & Saponin & $\begin{array}{l}\text { Carote } \\
\text {-noids }\end{array}$ & $\begin{array}{c}\text { Chloro-phyll } \\
\text { a }\end{array}$ & $\begin{array}{c}\text { Chloro-phyll } \\
\text { b }\end{array}$ & $\begin{array}{c}\text { Total } \\
\text { Chlorophyll }\end{array}$ & IC50 \\
\hline $\begin{array}{c}\text { Total } \\
\text { polyphenol }\end{array}$ & 1 & $0.66^{\mathrm{ns}}$ & $1^{*}$ & $0.51^{\mathrm{ns}}$ & $0.767^{\circ}$ & $0.954^{*}$ & $0.903^{* *}$ & $-0.87^{\prime \prime}$ & $-0.928^{* *}$ & $-0.929^{\prime \prime}$ & $0.997^{*}$ \\
\hline Flavonoids & & 1 & $0.67^{*}$ & $-0.14^{\mathrm{ns}}$ & $0.988^{\prime \prime}$ & $0.988^{* *}$ & $0.858^{* *}$ & $-0.917^{* *}$ & $-0.740^{\circ}$ & $-0.74^{*}$ & $-0.715^{\circ}$ \\
\hline Tannin & & & 1 & $0.505^{\mathrm{ns}}$ & $0.778^{*}$ & $0.959^{* *}$ & $0.907^{* *}$ & $-0.876^{\circ}$ & $-0.929^{* *}$ & $-0.93^{* *}$ & $0.998^{*}$ \\
\hline O-diphenol & & & & 1 & $\begin{array}{c}-0.013 \\
\text { ns }\end{array}$ & $0.303^{\text {ns }}$ & $\underset{\substack{0.324 \\
\text { ns }}}{0.32}$ & $-0.183^{\text {ns }}$ & $-0.505^{\text {ns }}$ & $-0.435^{\mathrm{ns}}$ & $\begin{array}{c}-0.467 \\
\text { ns }\end{array}$ \\
\hline Phytosterol & & & & & 1 & $0.924^{*}$ & $0.917^{*}$ & $-0.960^{*}$ & $-0.822^{*}$ & $-0.868^{* *}$ & $0.813^{*}$ \\
\hline Saponin & & & & & & 1 & $0.966^{*}$ & -0.966 & $-0.936^{*}$ & $-0.957^{* *}$ & $\begin{array}{c}- \\
0.974\end{array}$ \\
\hline carotenoids & & & & & & & 1 & $-0.982^{* \prime}$ & $-0.947^{*}$ & $-0.97^{\prime \prime}$ & $\begin{array}{c}- \\
0.924 "\end{array}$ \\
\hline Chlorophyll a & & & & & & & & 1 & $0.917^{\prime \prime}$ & $0.951^{* \prime}$ & $0.899^{\prime \prime}$ \\
\hline Chlorophyll b & & & & & & & & & 1 & $0.995^{* \prime}$ & $0.936^{\prime \prime}$ \\
\hline $\begin{array}{c}\text { Total } \\
\text { chlorophyll }\end{array}$ & & & & & & & & & & 1 & $0.941^{*}$ \\
\hline IC50 & & & & & & & & & & & 1 \\
\hline
\end{tabular}

\section{Principal component analysis (PCA)}

All collected data were submitted to principal component analysis (PCA) to better understand the changes of the phenolics, pigments, phytosterol and saponin contents of the studied leaves as function of various areas. The mean values of these compounds were used to build the PCA. Two principal groups concerned, with antioxidants compounds concentrations, were composed according to the PCA analysis.

The results showed a significant difference between Northern and Southern 'Meski' leaves on the level of total polyphenols, flavonoids, tannins, carotenoids, saponin and phytosterol compounds. The two first principal components (F1 and F2) explained $97.11 \%$ of the variance being F1 with $83.93 \%$ and F2 with 13.18\%. Total phenols, flavonoids, tannins, carotenoids, saponin and phytosterol of Southern leaves were selected positively according to $\mathrm{F} 1$ axis. Although, total chlorophyll, chlorophyll $a$ and $b$ were elected negatively to the axis F1, suggesting that these pigments were negatively correlated to the other antioxidant's compounds.

According to PCA, the response of 'Meski' cultivar to climatic variability was different. In Southern area, the production of total polyphenol, flavonoids, tannins and the accumulation of carotenoids, phytosterol and saponin increased in leaves. Although, Northern leaves produced more chlorophyll $a, b$ and total chlorophyll than the Southern ones. This result agreed with those of Khaleghi et al. (2012) and Cetinkaya et al. (2016) who showed that the water deficit induced a reduction of chlorophyll concentration in olive leaves, suggesting the sensitivity of this pigment to increase environmental stress. Since, the decreases of this pigment constitute a typical symptom of oxidative stress. Also, the study noted that the severity of climate positively affected the concentration of phenolic compounds, carotenoids, saponin and phytosterol, reduced total chlorophyll and increased the antioxidant capacity of leaves to shrink the effect of the environmental stress. This decline may be explained with the defense-related functions of phenolic compounds (Cetinkaya et al., 2016).

\section{Identification and quantification of chemical compound of leaves extract by GC-MS}

The analysis of leaves extract by CPG- FID and GC-MS of 'Meski', grown in various areas of Tunisia, was illustrated in Table 5 . The results showed that 53.44,59.4 and 55.39\% of compounds were identified in northern, in Center and in southern leaves of 'Meski' cultivar respectively. Seventy-three compounds of the olive methanolic extracts were identified in leaves from various origins, such as phenolics, hydrocarbons, terpenoids, carbonylic compounds, fatty acids, cetones and esters. 
Ben Mansour-Gueddes S et al. (2020). Not Bot Horti Agrobo 48(1):436-455

450

Table 5. Changes of biochemical compounds in olive leaves extracts according to various origins

\begin{tabular}{|c|c|c|c|c|}
\hline Compounds & $\begin{array}{c}\text { Retention } \\
\text { time } \\
(\mathrm{min})\end{array}$ & $\begin{array}{l}\text { Northern } \\
\text { leaves }\end{array}$ & $\begin{array}{l}\text { Center } \\
\text { leaves }\end{array}$ & $\begin{array}{c}\text { Southern } \\
\text { leaves }\end{array}$ \\
\hline \multicolumn{5}{|l|}{ Phenolic Compounds } \\
\hline hydroxymethylbenzene & 11.53 & 6.58 & & \\
\hline$\alpha$-ionene & 11.87 & & & 6.75 \\
\hline trimethyl-tetrahydronaphthalene & 11.88 & & 0.26 & \\
\hline Benzaldehyde & 12.50 & 1.55 & 3.52 & 5.28 \\
\hline Naphthalene, 1,2,3,4-tetrahydro-1,5,8-trimethyl- & 14.33 & & & 1.13 \\
\hline 1-(2,4,6-Trimethylphenyl)buta-1,3-diene & 17.57 & & & 0.56 \\
\hline Benzene,2-(1,3-butadienyl)-1,3,5-trimethyl- & 17.59 & 0.17 & & \\
\hline 3-Fluorocatechol & 17.70 & & & 0.3 \\
\hline Guaiacol & 17.79 & 1.48 & 2.4 & 3.07 \\
\hline Benzeneethanol & 18.60 & & 0.92 & \\
\hline 4-Methyl-2,6-di-tert-butylphenol (BHT) & 18.76 & 2.22 & & \\
\hline Phenol, 2-methyl- & 19.92 & 2.61 & & \\
\hline Phenol & 19.95 & 1.51 & & 0.42 \\
\hline 2-(t-butyl)benzothiophene & 20.07 & & & 0.26 \\
\hline 4-vinyl guaiacol & 22.53 & 2.18 & 7.77 & 5.32 \\
\hline 2,6-Dimethoxyphenol & 23.38 & 0.31 & & 0.94 \\
\hline Phenol, 2,5-bis(1,1-dimethylethyl) & 24.02 & & & 0.17 \\
\hline N,N'-di-sec-Butyl-1,4-benzenediamine & 24.03 & 0.29 & & \\
\hline $\begin{array}{l}\text { 1-6-dimethylamino-2-phenyl-3-methyl( 1-7- } \\
\text { methoxynaphthalene) }\end{array}$ & 24.48 & 1.71 & 3.94 & 1.81 \\
\hline 2-(dimethylamino)-3-phenylbenzo[b] thiophene & 27.36 & 0.35 & & \\
\hline $\begin{array}{c}\text { 5-Methylthio-3-(2-(3,4,5-trimethoxyphenyl) ethenyl }) \\
\text { pyrazole }\end{array}$ & 28.79 & 0.62 & 4.09 & \\
\hline 3,5'-biacenaphthene & 29.37 & 0.89 & & 2.47 \\
\hline Penoxaline & 30.86 & & & 15.32 \\
\hline Naphthalene, 1-phenyl-4-(1-phenylethenyl)- & 31.23 & & 1.21 & 0.37 \\
\hline 1-Phenyl-4-(1-phenylethenyl) naphthalene & 33.59 & 4.44 & 4.4 & 0.38 \\
\hline Total & & 26.3 & 28.51 & 44.55 \\
\hline \multicolumn{5}{|l|}{ Hydrocarbons } \\
\hline Dichloromethane ion & 3.32 & & 0.75 & \\
\hline Octamethyl-cyclotetrasiloxane & 3.85 & & & 0.67 \\
\hline 2-Hexyne & 9.52 & 0.25 & & \\
\hline 1,4-Pentadiene, 2,3,3-trimethyl- & 12.05 & & 0.38 & \\
\hline 5-Tetradecen-3-yne, $(Z)$ & 12.84 & 1.29 & & \\
\hline Dimethylsulfoxide(DMSO) & 13.48 & 2.51 & & 1.57 \\
\hline Cycloheptane & 16.39 & & 0.63 & \\
\hline 2-Methyl-1-octene & 18.28 & & 0.75 & \\
\hline 2-methyl-2-ethenyl-1,1- difluorocyclopropane & 19.69 & 0.17 & & \\
\hline 3,5'-biacenaphthene & 33.90 & 1.00 & 1.39 & 1.24 \\
\hline 10-Demethylsqualene & 38.40 & 9.35 & & \\
\hline Total & & 14.57 & 3.27 & 4.11 \\
\hline \multicolumn{5}{|l|}{ Terpenoids } \\
\hline \multicolumn{5}{|l|}{ Oxygenated hemiterpen } \\
\hline Oxirane, 2-ethyl-2-methyl- & 14.25 & 0.34 & & \\
\hline 2-Furanmethanol & 14.59 & 0.84 & 3.54 & 1.15 \\
\hline 3,4-Dihydropyran & 16.27 & 0.21 & 0.36 & 0.24 \\
\hline
\end{tabular}


Ben Mansour-Gueddes S et al. (2020). Not Bot Horti Agrobo 48(1):436-455

\begin{tabular}{|c|c|c|c|c|}
\hline 2(3H)-Furanone, 5-methyl- & 16.41 & 0.38 & & \\
\hline \multicolumn{5}{|l|}{ Monoterpen } \\
\hline (2-Methylprop-1-enyl)-cyclohexa-1,5-diene & 20.50 & & & 0.55 \\
\hline \multicolumn{5}{|l|}{ Sesquiterpen } \\
\hline 5-ethyl-1,3-dimethylindan & 15.74 & & & 0.24 \\
\hline Total & & 1.77 & 3.9 & 2.18 \\
\hline \multicolumn{5}{|l|}{ Carbonylic compounds } \\
\hline Furfural=2-Furancarboxaldehyde & 11.29 & 1.28 & 8.73 & 3.73 \\
\hline 3-Cyclohexene-1-carboxaldehyde & 23.79 & 2.43 & & \\
\hline Total & & 3.71 & 8.73 & 3.73 \\
\hline \multicolumn{5}{|l|}{ Fatty acids } \\
\hline Palmitic acid & 23.11 & 1.21 & 1.82 & 1.52 \\
\hline Total & & 1.21 & 1.82 & 1.52 \\
\hline \multicolumn{5}{|l|}{ Cetones } \\
\hline 4-(Diethylamino)-2-butanone & 7.87 & 0.37 & & \\
\hline Bicyclo [3.3.0] oct-1(2)-en-3-one & 15.03 & 4.78 & & \\
\hline Corylon=Cyclotene & 17.28 & 1.15 & 0.92 & 0.64 \\
\hline Ethanone, 1-(1,4-dimethyl-3-cyclohexen-1-yl)- & 17.98 & & 0.53 & \\
\hline Maltol & 19.28 & & 0.30 & \\
\hline Furaneol & 20.19 & & 0.77 & 0.46 \\
\hline 1,3-Dimethylbicyclo[3.3.0] oct-3-en-2-one & 21.28 & & 0.82 & \\
\hline Megastigmatrienone 4 & 22.81 & & & 1.86 \\
\hline 4H-Pyran-4-one,2,3-dihydro-3,5-dihydroxy-6-methyl- & 23.29 & & 0.64 & 0.37 \\
\hline 1-(2'-Norbornylidene) propan-2-one & 23.91 & & & 4.56 \\
\hline 2,6-Dimethyl-.delta.1-bicyclo[4.4.0]decen-8-one & 23.92 & & & 0.3 \\
\hline 3-Hydroxy-beta.-damascone & 26.82 & 0.38 & & 0.92 \\
\hline Bicyclo[3.2.0]hept-6-e n-2-one, 1-propyl- & 26.95 & & 2.48 & \\
\hline 1,3-Cyclopentanedione, 2-(2,2-dimethylpropylidene & 28.30 & & 9.47 & \\
\hline Dihydrojasmone & 29.79 & & 1.12 & \\
\hline Total & & 6.68 & 17.05 & 8.19 \\
\hline \multicolumn{5}{|l|}{ Ester } \\
\hline Hexadecanoic acid, methyl ester & 13.19 & 0.19 & & 0.21 \\
\hline Total & & 0.19 & & 0.21 \\
\hline \multicolumn{5}{|l|}{ Others } \\
\hline Dimethylsiloxanepentamer & 5.40 & 0.22 & & \\
\hline vitispirane & 12.77 & & 0.82 & \\
\hline 5-Methyl-2-furfural & 13.31 & & & 1.05 \\
\hline 1H-Pyrazole, 3-methyl- & 16.00 & & 0.26 & \\
\hline N-Formylpiperidine & 16.75 & 0.4 & & \\
\hline Ethanone, 1-(2-furanyl)- & 17.28 & & & 0.28 \\
\hline Methyl n-amyldisulfide & 23.52 & 0.84 & & \\
\hline Total & & 1.46 & 1.08 & 1.72 \\
\hline Total Identified Compounds (\%) & & 59.73 & 68.26 & 66.21 \\
\hline
\end{tabular}

Note: The analysis of leaves extract was realized by CPG- FID and GC-MS of Meski, grown in various areas of Tunisia

The content of phenolic compounds in leaves extract increased with the severity of climate from the North (26.3\%) to the South (44.33\%). The level of Guaiacol (3.07\%), Benzaldehyde (5.28\%) and Phenol, 2,5bis (1,1-dimethylethyl) increased in Southern leaves. These phenolic compounds could increase draught tolerance in leaves extract, while $\alpha$-ionene (6.75\%) and penoxaline (15.32\%) accumulated only in Southern area, which seemed to be an indicator of drought stress. The results are in agreement with those of Bacelar $e t$ 
452

al. (2006) who suggested that under environmental stress conditions, the production of total phenols in leaves increased.

Terpenes accumulated in higher quantity in Southern leaves of 'Meski' than in Northern ones. This result is in agreement with other studies and explained that terpene concentrations have been generally found to increase in drought conditions (Kainulainen et al., 1992; Llusia and Penuelas, 1998; Blanch et al., 2009). Also, Flamini et al. (2003) showed that aldehyde and terpene compositions changed significantly according to season in the leaves of an Italian olive cultivar. These secondary metabolites are reported to possess antioxidant potentials (Yasukazu and Takuma, 2008) and play a primordial role in the adaptation to surround the severity of the climate.

\section{Conclusions}

The present study showed a significant influence of the climate on the bioactive compounds content and the antioxidant activity of 'Meski' olive trees' leaves. To surround the aggression of climate and to provide tolerance to stress, olive tree 'Meski' increased phenolic compounds, flavonoids, tannins, phytosterols, saponin and carotenoids contents and decreased their chlorophyll levels in trees' leaves cultivated in Southern areas. The highest level of antioxidants compounds in Southern leaves could be contributed to increase the capacity of leaves to scavenging free radicals and to reduce the oxidative stress. Thus, it can be concluded that the biosynthesis and regulation of these secondary metabolites can be considered as a response of the tree to oppose the oxidative stress that results from the severity of climatic conditions, characteristic of the Southern area. Also, it is considered as an adaptation to the tree to survive and tolerate environmental stress.

\section{Acknowledgements}

The study was supported by the Laboratory of Amelioration of the Olive Tree Productivity and Product Quality. All authors are grateful to Dr. M. ABICHOU, Institute of Olive Tree, Station of Zarziz, for his contribution to collect the samples.

\section{Conflict of Interest}

The authors declare that there are no conflicts of interest related to this article.

\section{References}

Abaza L, Taamalli A, Nsir H, Zarrouk M (2015). Olive tree (Olea europaea L.) leaves: importance and advances in the analysis of phenolic compounds. Antioxidants 4(4):682-698.

Agarwal M, Zhu Jk (2005). Integration of abiotic stress signaling pathways: plant abiotic stress (Eds.). Blackwell Publishing, Oxford.

Aouidi F, Perraud I, Roussos S, Hamdi M (2007). Etude de la répartition quantitative des phénols totaux dans l'olivier en fonction des organes et leur degré de maturité. In: Karray B, Khecharem J, Sevastianos R. Proceeding Olivebioteq pp 376379.

Araújoa LBDC, Silva SL, Galvãoc MAM, Ferreiraa MRA, Araújod EL, Randaua KP, Soares LAL (2013). Total phytosterol content in drug materials and extracts from roots of a canthospermum hispidum by UV-VIS spectrophotometry. Revista Brasileira Farmacognosia 23(5):736-742. 
Arji I, Arzani K (2008). Effect of water stress on some biochemical changes in leaf of five olive (Olea europaea L.) cultivars. Acta Horticultura 791:523-526.

Arts MJT, Dalinga JS, Voss HP, Haenen GR, Bast A (2004). A new approach to assess the total antioxidant capacity using the TEAC assay. Biology et Medecine 88(4):575-570.

Aruoma OI (2003). Methodological considerations for characterizing potential antioxidant actions of bioactive components in food plants. Mutation Research/Fundamental and Molecular Mechanisms of Mutagenesis 523:9-20.

Ba K, Tine E, Destain J, Cissé N, Thonart P (2010). Etude comparative des composés phénoliques, du pouvoir antioxydant de différentes variétés de sorgho sénégalais et des enzymes amylolytiques de leur malt. Biotechnologie, Agronomie, Société et Environnement 14(1):131-139.

Baccou JC, Lambert F, Sauvaire Y (1977). Spectrophotometric method for the determination of total steroidal sapogenin. Analyst 102:458-465.

Bacelar EA, Santos DL, Moutinho-Pereira JM, Gonçalves BC, Ferreira HF, Correia CM (2006). Immediate responses and adaptive strategies of three olive cultivars under contrasting water availability regimes: changes on structure and chemical composition of foliage and oxidative damage. Plant Science 170(3):596-605.

Blanch S, Peñuelas J, Sardans J, Llusia J (2009). Drought, warming and soil fertilization effects on leaf volatile terpene concentrations in Pinus halepensis and Quercus ilex. Acta Physiologia Plantarium 31(1):207-218.

Blekas G, Psomiadou E, Tsimidou M, Boskou D (2002). The importance of total polar phenols to monitor the stability of Greek virgin olive oil. European Journal of Lipid Science and Technology 104(6):340-346.

Böttcher S, Drusch S (2017). Saponins-Self-assembly and behavior at aqueous interfaces. Advances in Colloid and Interface Science 243:105-113.

Boubakri H, Jdey A, Taamalli A, Taamalli W, Jebara M, Brini F, ... Verardo V (2017). Phenolic composition as measured by liquid chromatography/ mass spectrometry and biological properties of Tunisian barley. International Journal of Food Properties 20(2):1783-1797.

Boutté Y, Grèbe M (2009). Cellular processes relying on sterol function in plants. Current Opinion in Plant Biology 12(6):705713.

Brahmi F, Mechri B, Dabbou S, Dhibi M, Hammami M (2012). The efficacy of phenolic compounds with different polarities as antioxidants from olive leaves depending on seasonal variations. Industrial Crops and Products 38:146-152.

Brahmi F, Mechri B, Dhibi M, Hammami M (2014). Variation in antioxidant activity and phenolic content in different organs of two Tunisian cultivars of Olea europaea L. Acta Physiologiae Plantarum 36(1):169-178.

Cetinkayaa H, Koca M, Kulak M (2016). Monitoring of mineral and polyphenol content in olive leaves under drought conditions: application chemometric techniques. Industrial Crops and Products 88:78-84.

Choi CW, Kim SC, Wang SSH, Choi BK, Jahn H, Lee MY, ... Kim K (2002). Antioxidant activity and free radical scavenging capacity between Korean medicinal plants and flavonoids by assay-guided comparison. Plant Science 163(6):1161-1168.

Choi EM, Wang KH (2005). Screening of Indonesian medicinal plants for inhibitor activity on nitric oxide production of RAW 264.7 cells and antioxidant activity. Fitoterapia 76(2):194-203.

Choi JN (2002). External activities and team effectiveness: review and theoretical development. Small Group Research 33(2):181-192.

Dehpeur A, Ibrahim zadeh M, Fazel S, Mohammad S (2009). Antioxidant activity of the methanol extract of Ferula assafoetida and its essential oil composition. Grasas Y Aceites 60(4):405-412.

Demmig-Adams B, Adams WW (1996). The role of xanthophylls cycle carotenoids in the protection of photosynthesis. Trends Plant Science 1(1):21-26.

DGPA (2015). Direction Générale de Production Agricole, Ministère de l'Agriculture et de l'Environnement. Tunis, Tunisie.

El-Sayed AA, Razin AM, Swaefy HMF, Mohamed SM, Abou-Aitah KEA (2008). Effect of water stress on yield and bioactive chemical constituents of Tribulus species. Journal of Applied Sciences Research 4(12):2134-2144.

Falcone Ferreyra ML, Rius SP, Casati P (2012). Flavonoids: biosynthesis, biological functions, and biotechnological applications. Frontier in Plant Science 3:222.

Ferrer A, Altabella T, Arró M, Boronata A (2017). Emerging roles for conjugated sterols in plants. Progress in Lipid Research 67:27-37.

Flamini G, Cioni PL, Morelli I (2003). Volatiles from leaves, fruits, and virgin oil from Olea europaea cv. 'Olivastra Seggianese' from Italy. Journal Agricultural Food Chemistry 51(5):1382-1386.

Goupy P, Hugues M, Boivin PM, Amiot J (1999). Antioxidant composition and activity of barley (Hordeum vulgare) and malt extracts and of isolated phenolic compounds. Journal of the Science of Food and Agriculture 79(12):1625-1634. 
454

Grace SC (2005). Phenolics and antioxidants. In: SmirnoffN editor, Antioxidants and reactive oxygen species in plants. Oxford, UK.

Hanci F, Cebeci E (2014). Comparison of salinity and drought stress effects on some morphological and physiological parameters in onion (Allium cepa L.) during early growth phase. Bulgarian Journal of Agricultural Science 21(6):12041210.

Kainulainen P, Oksanen J, Holopainen JK, Holopainen T (1992). Effect of drought and water-logging stress on needle monoterpenes of Picea abies (L.). Canadian Journal of Botany 70(8):1613-1616.

Keys A (1995). Mediterranean diet and public health: Personal reflections. The American Journal of Clinical Nutrition 61(6):1321-1323.

Khaleghi E, Arzani K, Moallemi N, Barzegar M (2012). Evaluation of chlorophyll content and chlorophyll fluorescence parameters and relationships between chlorophyll $\mathrm{a}, \mathrm{b}$ and chlorophyll content index under water stress in Olea europaea cv. 'Dezful'. International Journal of Biological, Biomolecular, Agricultural, Food and Biotechnological Engineering 6:626-639.

Kolo Z (2016). Characterization of the role of a cycloartenol synthase gene (ZMCAS494) in Zea mays responses to drought stress. PhD Thesis, University of the Western Cape.

Lee OH, Lee BY, Lee J, Lee HB, Son JY, Park CS, ... Kim YC (2009). Assessment of phenolics enriched extract and fractions of olive leaves and the antioxidant activities. Bioresource Technology 100(23):6107-6113.

Leong LP, Shui G (2002). An investigation of antioxidant capacity of fruits in Singapore markets. Food Chemistry 76(1):69-75.

Lichtenthaler HK, Buschmann C (2001). Chlorophylls and carotenoids measurement and characterization by UV-VIS. In: Lichtenthaler HK, Editor. Current Protocols in Food Analytical Chemistry (CPFA), Wiley, NewYork pp F4-3.

Lin JT, Chen SL, Liu SC, Yang DJ (2009). Effect of harvest time on saponins in yam (Dioscorea pseudojaponica Yamamoto). Journal of Food and Drug Analysis 17(2):116-122.

Llusià J, Peñuelas J (1998). Changes in terpene content and emission in potted Mediterranean woody plants under severe drought. Canadian Journal of Botany 76(8):1366-1373.

Luo Y, Qin G, Zhang J, Liang Y, Song Y, Zhao M, ... Qu LJ (2011). D-myo-inositol-3-phosphate affects phosphatidyl inositolmediated endo membrane function in Arabidopsis and is essential for auxin-regulated embryogenesis. The Plant Cell 23(4):1352-1372.

Lv L, Zheng L, Dong D, Xu L, Yin L, Xu Y, ... Peng J (2013). Dioscin, a natural steroid saponin, induces apoptosis and DNA damage through reactive oxygen species: 0061 potential new drug for treatment of glioblastoma multiforme. Food and Chemical Toxicology 59:657-669.

Madland E (2013). Extraction, isolation and structure elucidation of saponins from Herni ariaincana. Norwegian University of Science and Technology, NTNU-Trondheim.

Morales M, Zapata S, Jaimes TR, Rosales S, Alzate AF, Maldonado M, ... Rojano BA (2017). Mangiferin content, carotenoids, tannins and oxygen radical absorbance capacity (ORAC) values of six mango (Mangifera indica) cultivars from the Colombian Caribbean. Journal of Medicinal Plants Research 11(7):144-152.

Odjegba VJ, Alokolaro AA (2013). Simulated drought and salinity modulates the production of phytochemicals in Acalypha wilkesiana. Journal of Plant Studies 2(2):105-112.

Ozcelik B, Lee JH, Min DB (2003). Effects of light, oxygen, and pH on the absorbance of 2,2-diphenyl-1-picrylhydrazyl. Journal of Food Sciences 68(2):487-490.

Pandey S, Fartyal D, Agarwal A, Shukla T, James D, Kaul T, ... Reddy MK (2017). Abiotic stress tolerance in plants: myriad roles of ascorbate peroxidase. Frontiers in Plant Science 8:1-13.

Papoti VT, Tsimidou MZ (2009). Impact of sampling parameters on the radical scavenging potential of olive (Olea europaea L.) leaves. Journal of Agricultural and Food Chemistry 57(9):3470-3477.

Petridis A, Therios I, Samouris G (2012). Genotypic variation of total phenol and oleuropein concentration and antioxidant activity of 11 Greek olive cultivars (Olea europaea L.). Hortscience 47(3):339-342.

Re R, Pellegrini N, Proteggente A, Pannala A, Yang M, Rice-Evans C (1999). Antioxidant activity applying an improved ABTS radical cation decalorization assay. Free Radical Biology and Medicine 26(9-10):1231-1237.

Rout NP, Shaw BP (2001). Salt tolerance in aquatic macrophytes: possible involvement of the antioxidative enzymes. Plant Science 160(3):415-423.

Ryan D, Robards K, Lavee S (1999). Change in phenolic content of olive during maturation. International Journal of Food Science and Technology 34(3):265-274. 
Sharma P, Dubey RS (2005a). Drought induces oxidative stress and enhances the activities of antioxidant enzymes in growing rice seedlings. Plant Growth Regulation 46(3):209-221.

Shimoi K, Masuda S, Shen B, Furugori B, Kinae N (1996). Radioprotective effect of antioxidative plant flavonoids in mice. Mutation Research 350(1):153-161.

Silva KDRR, Sirasa MSF (2018). Antioxidant properties of selected fruit cultivars grown in Sri Lanka. Food Chemistry 238:203208.

Taamalli A, Arráez D, Barrajón E, Ruiz V, Pérez A, Herrero M, ... Fernández A (2012). Use of advanced techniques for the extraction of phenolic compounds from Tunisian olive leaves, phenolic composition and cytotoxicity against human breast cancer cells. Food and Chemical Toxicology 50(6):1817-1825.

Talhaoui N, Gómez-Caravaca AM, León L, De la Rosa R, Fernández-Gutiérrez A, Segura-Carretero A (2016). From olive fruits to olive oil: phenolic compound transfer in six different olive cultivars grown under the same agronomical conditions. International Journal of Molecular Science 17(3):337.

Thaipong K, Boonprakob U, Crosby K, Cisneros-Zevallos L, Hawkins Byrne D (2006). Comparison of ABTS, DPPH, FRAP, and ORAC assays for estimating antioxidant activity from guava fruit extracts. Journal of Food Composition and Analysis 19(6-7):669-675.

Top SM, Preston CM, Dukes JS, Tharayil N (2017). Climate influences the content and chemical composition of foliar tannins in green and senesced tissues of Quercus rubra. Frontiers in Plant Sciences 8:423.

Turkoglu A, Duru ME, Mercan N, Kivrak I, Gezer K (2007). Antioxidant and antimicrobial activities of Laetiporus sulphureus (Bull.). Murrill. Food Chemistry 101(1):267-273.

Vrieta C, Russinovae E, Reuzeau C (2013). From squalene to Brassinolide: the steroid metabolic and signaling pathways across the plant kingdom. Molecular Plant 6(6):1738-1757.

Wujeska A, Bossinger G, Tausz M (2013). Responses of foliar antioxidative and photoprotective defence systems of trees to drought: a meta-analysis. Tree Physiology 33(10):1018-1029.

Yasukazu O, Takuma S (2008). Antioxidant and photo-antioxidant activities of chalcone derivatives. Journal of the Japan Petroleum Institute 51(5):298-308.

Yu H, Zheng L, Yin L, Xu L, Han Y, Youwei QX, ... Liu JP (2014). Protective effects of the total saponins from Dioscorea nipponica Makino against carbon tetrachloride-induced liver injury in mice through suppression of apoptosis and inflammation. International Immunopharmacology 19(2):233-244.

Yu L, Halley S, Perret J, Palma M, Wilson J, Qian M (2002). Free radical scavenging properties of wheat extracts. Journal of Agricultural and Food Chemistry 50(6):1619-1624.

Zeitoun MAM, Mansour HMM, Ezzat S, El Sohaimy SA (2017). Effect of pretreatment of olive leaves on phenolic content and antioxidant activity. American Journal of Food Technology 12(2):132-139.

Zhang Y, Giboulot A, Zivy M, Valot B, Jamet E, Albenne C (2011). Combining various strategies to increase the coverage of the plant cell wall glycoproteome. Phytochemistry $72(10): 1109-1123$.
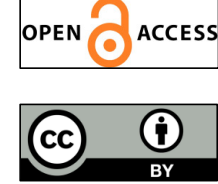

The journal offers free, immediate, and unrestricted access to peer-reviewed research and scholarly work. Users are allowed to read, download, copy, distribute, print, search, or link to the full texts of the articles, or use them for any other lawful purpose, without asking prior permission from the publisher or the author.

License - Articles published in Notulae Botanicae Horti Agrobotanici Cluj-Napoca are Open-Access, distributed under the terms and conditions of the Creative Commons Attribution (CC BY 4.0) License. (c) Articles by the authors; UASVM, Cluj-Napoca, Romania. The journal allows the author(s) to hold the copyright/to retain publishing rights without restriction. 